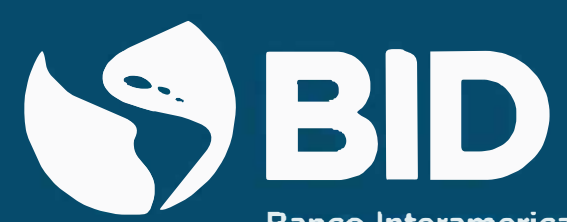

Banco Interamericano de Desarrollo

\title{
A brighter future: The impact of rural school electrification programs on the dropout rate in primary education in Brazil.
}

Energy Division

TECHNICAL NOTE N ${ }^{\circ}$ IDB-TN-1590

Alexandre Mejdalani Roberta Mendes e Costa Michelle Hallack David Lopez Miguel Vazquez 


\section{A brighter future: The impact of rural school electrification programs on the dropout rate in primary education in Brazil}

Energy Division

Infrastructure and Energy Sector

Alexandre Mejdalani; Roberta Mendes e Costa; Michelle Hallack; David Lopez; Miguel Vazquez 


\section{Cataloging-in-Publication data provided by the Inter-American Development Bank Felipe Herrera Library}

A brighter future: The impact of rural school electrification programs on the dropout rate in primary education in Brazil / Alexandre Mejdalani, Roberta Mendes e Costa, Michelle Hallack, David Lopez, Miguel Vazquez.

p. cm. - (IDB Technical Note ; 1590)

Includes bibliographic references.

1. Elementary school dropouts-Prevention-Brazil. 2. Rural electrification-Brazil. 3.

Education, Rural-Brazil. 4. Rural public utilities-Brazil. I. Mejdalani, Alexandre. II. Mendes e Costa, Roberta. III. Hallack, Michelle, 1983- IV. Lopez, David. V. Vazquez, Miguel. VI. Inter-American Development Bank. Energy Division. VII. Series.

IDB-TN-1590

JEL Code: Q41; Q48; 124

Keywords: School dropout; Rural education; rural electrification; Brazil

Copyright (C) 2018 Inter-American Development Bank. This work is licensed under a Creative Commons IGO 3.0 Attribution-NonCommercial-NoDerivatives (CC-IGO BY-NC-ND 3.0 IGO) license

(http://creativecommons.org/licenses/by-nc-nd/3.0/igo/legalcode) and may be reproduced with attribution to the IDB and for any non-commercial purpose. No derivative work is allowed. Any dispute related to the use of the works of the IDB that cannot be settled amicably shall be submitted to arbitration pursuant to the UNCITRAL rules. The use of the IDB's name for any purpose other than for attribution, and the use of IDB's logo shall be subject to a separate written license agreement between the IDB and the user and is not authorized as part of this CC-IGO license.

Any dispute related to the use of the works of the IDB that cannot be settled amicably shall be submitted to arbitration pursuant to the UNCITRAL rules. The use of the IDB's name for any purpose other than for attribution, and the use of IDB's logo shall be subject to a separate written license agreement between the IDB and the user and is not authorized as part of this CC-IGO license.

Note that link provided above includes additional terms and conditions of the license.

The opinions expressed in this publication are those of the authors and do not necessarily reflect the views of the Inter-American Development Bank, its Board of Directors, or the countries they represent.

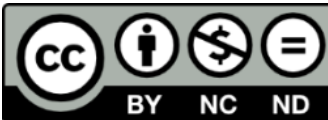




\section{Contents}

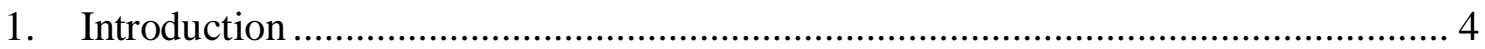

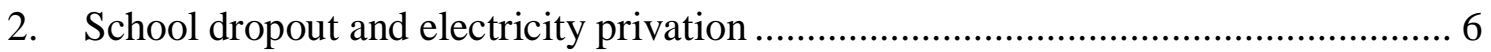

3. Case Study: the Brazilian experience with the"Light for All in Schools" program 10

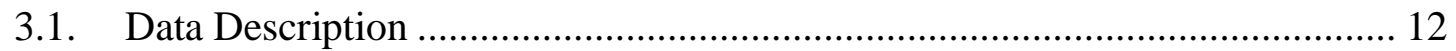

3.2. Method and Preliminary Testing …............................................................. 14

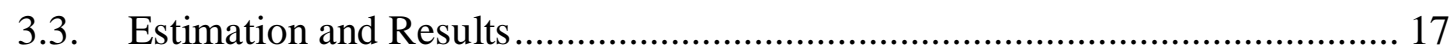

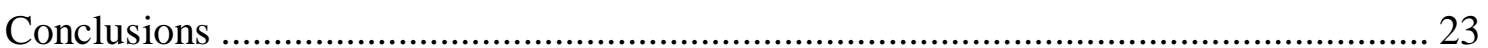

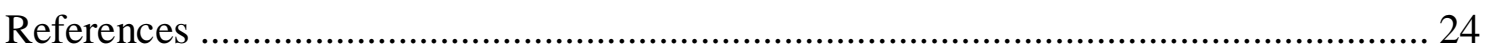




\section{Introduction}

Universal access to energy became one of the 17 Millennium Development Goal of the United Nations in 2015. Energy access was recognized as a key element for improving socio-economic conditions in developing countries. Access to energy services is expected to have a multi-dimensional impact on the potential of socio-economic development of a region, improving productivity, education, and health. Even if this relationship is intuitive, the evidence of the impact of energy access on the wellbeing of households is still a challenge (see for instance, Bharracharyya, 2012). There is an effort to look for and measure evidence, for instance Dinkelman (2011) shows the positive impact on employment for South Africa, Khandker et al. (2012) shows the impact of access on decreasing poverty in India. Lipscomb et al. (2013) find evidence in Brazil of the positive effects of electrification on the development index by looking long-term trends (19602000). Jimenez (2017) shows how over 50 impact evaluation studies demonstrate the overall positive impact of energy access. However, there are significant differences among the cases.

To find measurable evidence is relevant to the process in order to estimate the benefits of access policies and to improve the design of these policies. Our study contributes to this literature by showing evidence of the impact of school energy access on education in Brazil.

Education is important for many reasons. It produces individual and collective socioeconomic benefits. It is one of the main determinants of individual income, which means it also plays an essential role in income inequality (Belfield, 2000). Inequality in terms of educational opportunity results in income disparities due to the slim chance that the poorest will achieve secondary and higher education (especially the latter), impairing the reduction of income inequality (Ney, Souza and Ponciano, 2010). Promoting basic education in a country like Brazil, a country with significant rates of inequality and poverty, is a necessary condition for the full exercise of citizenship and participation in the modern economy.

Teixeira e Menezes-Filho (2012), using a Mincer equation ${ }^{1}$ with an instrumental variable approach and data from 1997 to 2007, estimate that a year of schooling in 
primary education increases an individual's wage income by $5.5 \%$ in Brazil. This figure might seem low, but we should keep in mind that in 2007, $95 \%$ of children age six to 14 were enrolled in primary education. ${ }^{2}$ An additional year of higher education, for instance, has a greater impact on wages. In addition, the mean years of schooling in the sample used by the authors is eight years, which is certainly higher than in the rural communities discussed in this paper. Considering this, the returns on primary education in these communities are likely higher than 5.5\%. Estimating a Mincer equation for a rural area is complex due to certain inherent characteristics such as the seasonal nature of rural wages.

Since 1988, the Brazilian Federal Constitution has established education as a social right with universal access to all grades of basic education (primary and secondary education). Therefore, isolated communities have the constitutional right to claim access to regular education in a public school. However, the infrastructure of these schools is precarious (Pieri e Santos, 2014). These schools usually lack access to basic services, such as drinkable water and electricity. The absence of these services may affect the daily life of the school community, including the ability of students to finish all grades. As of $2017,65.3 \%$ of the 16-year-old rural population had at least finished their primary education. While that number has steadfastly increased since 2012, it is still 12.7 p.p. less than the urban figure, $78 \%$ (Inep, 2018).

Particularly, the effects of electricity on learning are directly related to the availability of artificial lighting (among others, like cooling and food storage). Its benefits are innumerous. Artificial lighting extends possible teaching and studying hours, which is important in rural areas where students usually work on family farms during the daytime. It might also help increase teacher quantity and quality, given that rural schools have greater difficulty attracting and retaining (good) teachers. In fact, appropriate lighting seems to have positive returns on learning. For instance, Dunn et al. (1985) found that children that feel more comfortable under light perform better in a brighter environment. Sleegers et al. (2012) showed that an adequate lighting system has positive effects on pupils' concentration. Further, electrification might increase the attractiveness of schools and encourage attendance.

\footnotetext{
${ }^{1}$ The Mincer earnings function explains wage income as a function of schooling and labor market experience.

${ }^{2}$ Observatório do PNE. 2 - Ensino Fundamental. Available at

http://www.observatoriodopne.org.br/metas-pne/2-ensino-fundamental.
} 
Despite great improvement in the last decade, school dropout rates remain a relevant issue, especially for rural schools. Dropout rates are much higher among poorer families (Leon and Menezes-Filho, 2002; Ney, Souza and Ponciano, 2010), working students (Leon and Menezes-Filho, 2002; Verner and Cardoso, 2007) and low-performing students (Leon and Menezes-Filho, 2002) in Brazil. These three issues match the profile of rural communities that are a part of the Light for All program (or LFA, Programa Luz para Todos, in Portuguese). The program aims to "provide free access to electricity to rural families" (our translation), in particular to rural schools, quilombos, ribeirinhos, and small farmers. The branch of LFA focused on schools is the Light for All in School (or LFAS, Luz para Todos na Escola, in Portuguese), that provides electricity to schools without access to electricity. As mentioned above, electricity has many potential returns for education, including increasing learning and decreasing school dropout rates, which LFAS expects to improve. This study aims to measure the effect of access to electricity in rural schools on the dropout rate of students in primary education. Our goal is to create a dialogue between the studies on the benefits of electricity in vulnerable areas and the studies on education outcomes, contributing to this growing research area. We hope that our research helps to clarify the social returns of electricity provision to vulnerable rural regions and the impact on educational outcomes.

Our results show that electrification programs, like the LFAS, have a significant effect on the dropout rate of rural schools. These results demonstrate that electricity universalization programs have positive externalities not directly measured by a traditional cost-benefit analysis of the impact of electrification. Also, it provides hard evidence that proper infrastructure for teaching and learning during the initial years of schooling plays an important role in retaining children at school and thus potentially reduces child labor. Moreover, the gains that programs like the Light for All in Schools have made in rural areas help reduce inequality, first by reducing the educational gap between areas with different urbanization levels and, second by providing higher human capital to less-developed regions.

\section{School dropout and electricity privation}

Studies generally attribute the beginning of education economics as a research field to Gary Becker's (Machin and Vignoles, 2005). development of the theory of human 
capital in the 1960s. Since then, the field has branched out to encompass many research questions and has moved beyond answering why individuals invest in their own education.

There are two common topics in education economics relevant to this paper. The first is the estimation of the education production function, which relates inputs to educational outcomes. In essence, the microeconomics' theory of the firm is applied to education, thereby treating schools as educational enterprises (Belfield, 2000). Studies have shown the impact of several inputs on school outcomes, including school infrastructure.

The second is the evaluation of education initiatives, which aims to assess the impact of policy on education outcomes. Since resources are scarce, policymakers are interested in knowing which interventions achieve goals. The most widely used evaluation method is the differences-in-differences approach (Machin and Vignoles, 2005). Another key instrument in assisting policymakers on allocating scarce resources is the cost-benefit analysis. However, we were not able to do a cost-benefit analysis due to lack of information regarding program costs.

These two research branches face a similar issue: which school outcome should be investigated? Studies and policy-makers use scores from standardized tests to evaluate the effectiveness of schools. However, maximizing student learning, defined by specific metrics captured by these tests, may not be the only goal of a school or an education system. These goals are defined by societies and can be varied and interchangeable. Rumberger and Palardy (2005) argue that using only standardized tests provides an incomplete view of school performance and may result in erroneous conclusions about which schools are effective and which characteristics promote effectiveness.

Given that most national studies rely on standardized test results (Felicio, 2008), using alternative indices is relevant because they address the varied goals of schools (Rumberger and Palardy, 2005). For example, ensuring that students complete their education can be as important as improving their academic performance (Rumberger and Palardy, 2005). School attendance and dropout rates show different trends throughout basic education and in urban and rural settings. Data from the 2010 Demographic Census shows an overrepresentation: although only $18.6 \%$ of the population aged four to 17 years-old lives in rural areas, $27 \%$ of those who dropped out of school live in rural areas 
(Alves and Silva, 2013). As Table 1 shows, despite the decrease in dropout rates between 2007 and 2017, the rate is still higher in rural areas in 2017. Moreover, the decrease between the two years was steeper in urban schools.

Table 1. Dropout rates by stage of basic education and area - Brazil, 2007 and 2017

\begin{tabular}{c|c|c|c|c}
\hline & \multicolumn{2}{|c|}{2007} & \multicolumn{2}{c}{2017} \\
\hline & $\begin{array}{c}\text { Primary } \\
\text { Education }\end{array}$ & $\begin{array}{c}\text { Secondary } \\
\text { Education }\end{array}$ & $\begin{array}{c}\text { Primary } \\
\text { Education }\end{array}$ & $\begin{array}{c}\text { Secondary } \\
\text { Education }\end{array}$ \\
\hline All areas & 4.8 & 13.2 & 1.6 & 6.1 \\
\hline Urban & 4.4 & 13.2 & 1.4 & 6.1 \\
\hline Rural & 6.9 & 14 & 2.9 & 7.5 \\
\hline
\end{tabular}

Source: Own elaboration with data from National Institute of Educational Studies and Researches "Anísio Teixeira" (INEP). Retrieved October 23, 2018 from http://portal.inep.gov.br/web/guest/indicadoreseducacionais.

Basic education in Brazil is divided into three stages: $i)$ child education (children between 4 and 6 years old); ii) primary education covers nine years (children between seven and 14 years old); and, iii) secondary education has a minimum duration of three years (young people between 15 and 17-years-old). While primary education has been compulsory since 1971, secondary education only became mandatory in 2009 by Constitutional Amendment n. 59 (Alves and Silva, 2013).

Aware of the socioeconomic differences between urban and rural areas, most research tends to study urban and rural schools separately. In fact, since only $11 \%$ of basic education students are enrolled in rural schools, rural education has received less focus in Brazilian studies. ${ }^{3}$ Given this and the data discussed above, it is reasonable to assume that school attendance and dropout rates are different phenomena given the varied educational stages and geographic areas. Moving forward, we will focus on studying rural schools providing elementary education.

In general, schools and classes are smaller in rural areas, and there is the need to provide transport for students and teachers. Thus, the cost per student at rural schools is higher than in urban schools (Alves and Silva, 2013). Rural areas have higher poverty levels, adults have fewer years of schooling, and public services are provided at a lower quality. Problems related to intergenerational poverty are persistent and worsened by the

\footnotetext{
${ }^{3}$ Data from the Statistics Synopsis of Basic Education - National Institute of Educational Studies and Researches "Anísio Teixeira" (INEP). Retrieved October 23, 2018 from http://portal.inep.gov.br/web/guest/sinopses-estatisticas-da-educacao-basica.
} 
inequality of educational opportunities (Ney, Souza and Ponciano, 2010). Moreover, there is the enduring problem of child labor.

With data from the National Household Sample Survey (PNAD) from 2007, Ney, Souza, and Ponciano (2010) analyzed rates of finishing primary education in urban and rural areas. In both geographic areas, school dropout occurs mainly from the fourth year onward, and it is highest for the poorest (below $40 \%$ in the income distribution). ${ }^{4}$ Even so, dropout rates are highest in rural areas in all levels of primary education. Looking at young people between 17 and 19 years old in rural areas, while $73 \%$ of the richest (above $80 \%$ in the income distribution) finish their primary education, only $39 \%$ of the poorest acquire that education level.

Parents with low education levels are probably unaware of the import role education plays in social ascension. Considering how high inequality in educational opportunities is in rural areas, intergenerational poverty plays a significant role (Ney, Souza and Ponciano, 2010; Kassouf, 2015).

\section{The effects of electricity (absence) on learning}

The electrification of rural schools can improve education in diverse ways. It can affect school performance indirectly through improvement in infrastructure, such as water treatment, sanitation, heating, and cooling. Direct effects might occur via children being able to read and write more easily and via increased study time, concentration and motivation. Further, electrification might increase the attractiveness of schools and encourage attendance. For instance, one study found that electrification increased the likelihood of having a secondary school degree in Peru and Ghana (Welland, 2018).

Electrification might increase teacher quantity and quality, given that rural schools have greater difficulty attracting and retaining (good) teachers. Energy access can also enable the use of computers and other information and communication technologies (ICT) and the use of school buildings for adult literacy in the evenings (Welland, 2018).

Moreover, the electrification of schools may also have positive externalities for communities, such as improved water and sanitation and greater resilience to natural disasters (Welland, 2018). Diniz et al. (2006) report a decrease in illiteracy and an

\footnotetext{
${ }^{4}$ Primary education is divided between first years $(1-4)$ and final years (5 - 9). Other studies (Leon and Menezes-Filho, 2002) also verify a higher dropout rate at the end of the education cycle.
} 
improvement in educational opportunities in poor municipalities in Minas Gerais state, which participated in a rural school electrification program.

\section{Case Study: the Brazilian experience with the "Light for All in Schools" program}

The program "Luz para Todos" (in English "Light for All", hereunder LFA) was created in 2003 through an executive order" (EO) and is officially called the "National Program for the Universalization of Electricity Access and Usage - Light for All.” The program was originally supposed to operate from 2003 to 2010 but was expanded by four consecutive EOs (2008, 2010, 2011, 2014 and 2018) until 2022. According to the Ministry of Mines and Energy, 16.4 million people received electricity in their home from 2004 to 2017. Currently electricity access in Brazil reaches $99.3 \%$ of the population, according to the OLADE (2017) ${ }^{6}$. Regarding this premise and goal, the EO (2011) states that "[the program] intends to provide access to electricity to the rural population which does not have access to this public service" (our translation). In its fifth article, the EO (2003) establishes as a priority "projects of rural electrification of public schools (...)," from which the program derived the name "Light for All in Schools." Although schools are one priority of the program, they are below (a) rural houses below the poverty line, (b) houses within cities without basic living infrastructure and (c) rural family settlements, indigenous communities, quilombos, and other small communities.

In Figure 1, we draw the operation scheme of the program. The program is organized into four hierarchical levels: (1) coordination, (2) operation, (3) school assessment and (4) execution. The Ministry of Mines and Energy (MME) of Brazil coordinates the program and is responsible for defining its goals and deadlines. The operation is the responsibility of Eletrobras and its subsidiaries. ${ }^{7}$ The Ministry of Education is responsible for evaluating schools without access to electricity during the yearly school census. Then, Eletrobras informs local management committees which schools do not have access to energy. Local Commissions demand that local executors

\footnotetext{
${ }^{5}$ Executive Order number 4,873 / 2003.

${ }^{6}$ Even if Brazil achieved a high rate of electrification, there are still more than 1.4 million people without energy access. Some isolated rural areas still lack electricity benefits, such as lighting and refrigeration. This "last mile" problem excludes a small but extremely vulnerable share of the Brazilian population, like poor rural communities from semi-arid regions, Amazon riverside (also known as "ribeirinhos") and indigenous communities, and quilombos (century-old settlements founded by people of African origin who escaped from slavery).

${ }^{7}$ Eletrobras is a mixed public-private company with electricity distribution, transmission and generation operations.
} 
(power concessionaires) provide electricity access. Power concessionaires elaborate a work schedule for energy provision, which is approved by Eletrobras, and execute the connection of the schools. Both the National Management Committee for Universalization and the Brazilian electricity regulatory agency (ANEEL) assess program performance.

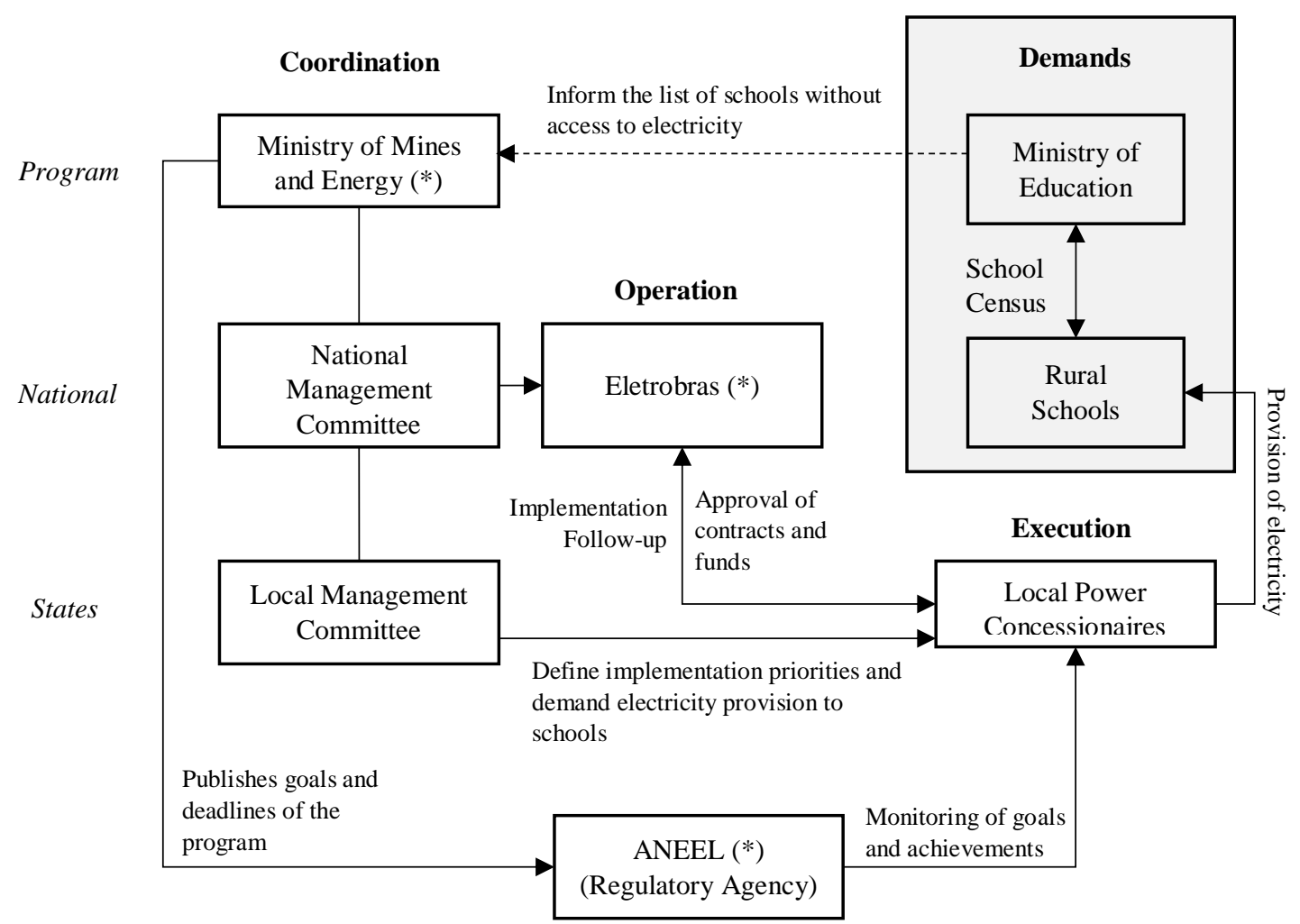

(*) Members of the National Management Committee for Universalization

Figure 1. Operational Flow Chart of "Light for All in Schools"

Source: Our elaboration based on the "Manual of Operation" (2015) and information provided by the Ministry of Mines and Energy

The LFA projects can have three sources of funding: (i) subventions, (ii) public financing and (iii) local concessionaires' own resources. The subvention is a direct transfer from two sources, the "Energy Development Account"8 (CDE) and the "Global

\footnotetext{
${ }^{8}$ In 2002, the Energy Development Account (CDE, in Portuguese: Conta de Desenvolvimento Energético) is created aiming the energy development of states and competitiveness of power generation of wind, small hydro, biomass, natural gas and coal. In particular, the CDE creation aimed to provide universal electricity.
} 
Reversion Reserve"9 (RGR), to local executors in order to mitigate regional deficiencies of funds or tariff impacts. Public financing is a contract available to local executors by Caixa Econômica Federal (CAIXA, a government-owned bank) with the technical supervision of Eletrobras. The total cost of the program financed by the CDE, RGR, and Caixa was BRL 9.87 billion (deflated by the Consumer's Price Index up to 2017), as reported by the MME in 2017 (BRL 608.71 per person or 2911.62 per family connected).

From a technical perspective, Power Concessionaires may provide electricity ongrid (connecting the school) or off-grid (by providing microgeneration facilities). The program operation manual provides five options of decentralized power generation: (i) micro hydro (< $100 \mathrm{~kW}$ ) or mini hydro (from $100 \mathrm{~kW}$ to $1 \mathrm{MW}$ ), (ii) small hydro (from $1 \mathrm{MW}$ to $30 \mathrm{MW}$ ), (iii) small thermal power station (diesel or biomass), (iv) solar or wind micro-generation, (v) hybrid system combining previous options.

Thus, program governance, operation, and financing follow a very complex scheme, with many decision levels and many ways to calculate the costs and benefits of electrification. The benefits of the Light for All projects, like the LFAS, are still being evaluated. The objective of this case study is to highlight the benefit of the LFAS on the dropout rate in initial years of schooling.

\subsection{Data Description}

We use two main datasets: School Census of Basic Education, from the Ministry of Education of Brazil (MEC), and Light for All in Schools (LFAS) list of participants, from the Ministry of Mines and Energy (MME). The first database is publicly available but the second is only available via request. The Brazilian School Census is an annual survey published by the National Institute of Educational Studies and Researches "Anísio Teixeira" (INEP), tied to the Ministry of Education. It is a national survey that covers private and public schools, from primary to secondary education, including vocational schools. The School Census also gathers data on educational establishments, classes,

Latter, an Executive Order (EO 4521) provided guidelines regarding the source of funds and using of the CDE.

\footnotetext{
${ }^{9}$ The Global Reversion Reserve (RGR, in Portuguese, "Reserva Global de Reversão") was created in 1957 by the EO 41,019 and aim to expand and improve the quality of the public provision of electricity. The reserve comes from sector charges payed by power concessionaires with an aliquot of $2.5 \%$ of the fixet asset of the company, with a cap of $3 \%$ of the revenues.
} 
students, and school professionals. We used two censuses, 2013 and 2016, which gives us a two-period panel. The Light for All in Schools list of participants is a database covering all schools identified as having improper access to electricity or no access at all by the Ministry of Education. The Ministry of Education geolocalized these schools and informed the Ministry of Mines and Energy which schools to include in the "Light for All" program. The data is available by request and the access to it is guaranteed by the federal Information Access Law (n. 12.527/2011). The last version of LFAS database was updated between February/2014 and June/2015.

The MEC/MME database identifies 8,534 schools included in the LFAS program. We excluded schools that cannot be localized by the MEC. Moreover, 1,525 schools were no longer active in 2016 (of which, 1,926 were suspended for specific reasons, like union strikes; $69.51 \%$ of them did not have electricity connection in 2013). Our final database contains 13,824 observations and 6,912 schools. Of those, $97.8 \%$ have primary school programs, while only $1.23 \%$ have secondary school programs. Compared to the other schools in the Census, these schools represent, on average, 55\% of schools reported as "without access" (Figure 2). Notice that the electrification rate has been rising since 2013. $12.9 \%$ per year in LFAS beneficiaries and $3.66 \%$ per year in schools outside of the program.

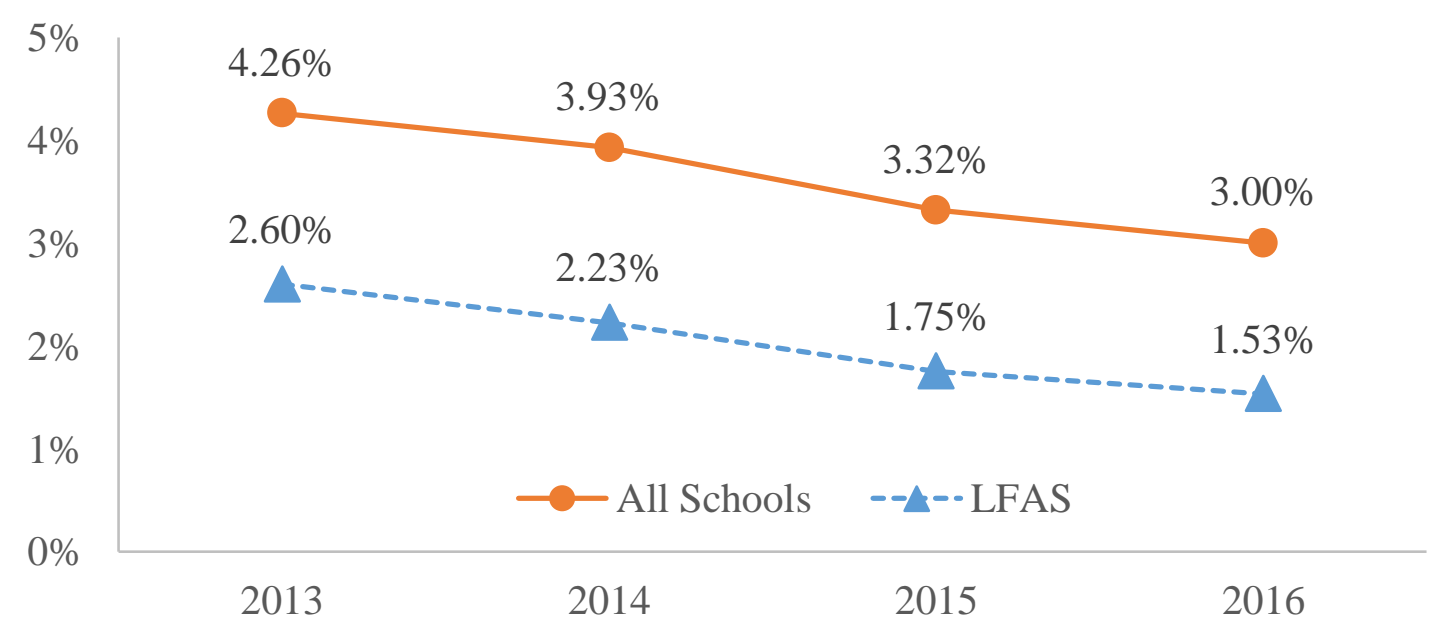

Figure 2. Percentage of schools in the Census without access to electricity

Source: Our elaboration

Figure 3 describes the electricity status of all active schools in our database. We have 1,372 treated schools (19.9\%) versus 2,686 electable but untreated schools (38.9\%). Also, $2.84 \%$ got disconnected from the grid, and $38.40 \%$ were treated before 2013 and kept the 
connection in 2016. While $60.7 \%$ of the schools in 2013 were disconnected in 2013, the share fell to $41.70 \%$ in 2016.

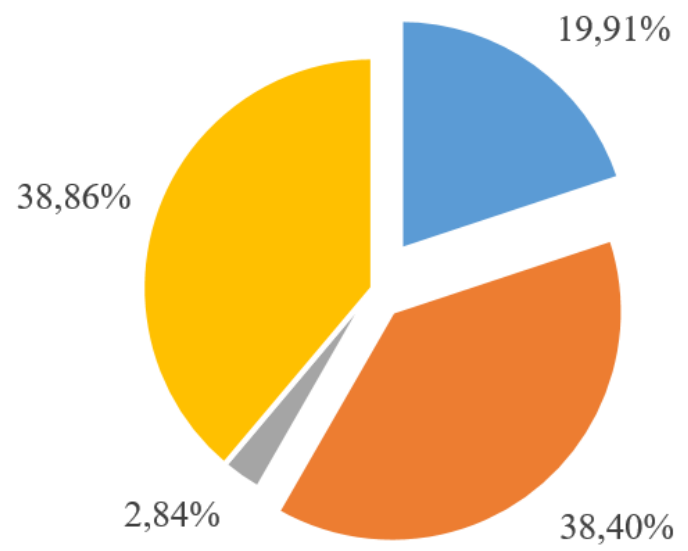

$\begin{array}{ll}\text { - Received electricity after } 2013 & \text { - Received electricity before } 2013 \\ \text { - Lost electricity since } 2013 & \text { - Disconnected until } 2016\end{array}$

Figure 3. Percentage of active schools in the program by electrification status in 2016 Note: Detached slice is considered as "treated"

Source: Our elaboration

\subsection{Method and Preliminary Testing}

We proceeded with two tests. First, we checked the electrification pattern. We classified schools by four types of electrification status: received electricity (i) before 2013, (ii) between 2013 and 2016, (iii) lost electricity between 2013 and 2016 and (iv) did not have electricity until 2016. We use the log-likelihood estimation from the multinomial logit regression model to check it, keeping category (i) as a control state. The Multinomial Logit is a useful tool to estimate the response of unordered categorical variables (Menard, 2010). The purpose of using this model is to check if the probabilities of the electrification status can be explained by the region and the characteristics of the community. The dependent variable to be estimated is the probability $P$ of having the categorical variable $Y_{i}$ it in state $m$. Or $P\left(Y_{i}=m\right)$. Thus, we estimate:

$$
P\left(Y_{i}=m\right)=\frac{\exp \left(Z_{m i}\right)}{1+\sum_{h=2}^{M} \exp \left(Z_{h i}\right)}
$$


Where $Z_{h i}$ is the log-odds of each response model, following the distribution of

$$
Z_{h i}=\log \frac{P\left(Y_{i}=m\right)}{P\left(Y_{i}=\text { baseline }\right)}=\alpha_{h}+x_{i}^{\prime} \beta_{h}
$$

In our model, the vector of variables $x$ includes: (i) one dummy identifying indigenous communities, (ii) one dummy identifying quilombola communities, (iii) four regional dummies, identifying the Northeast, the North, the South, and the Southeast. The model omitted the "No Energy" (up to 2016) state - as the baseline, and the Central West region control.

We describe the results of this first test below (Table 2). For electrified schools, all control variables - except for the North and Indigenous Communities in Status 3 - show a significant confidence level of $95 \%$. This indicates that the electrification status of "has access to electricity" can be explained by a set of variables with a fitness of 0.078 . Looking at the signals, we register Indigenous Communities and North with negative effects on status 4 (electrified before 2013), while the same variables show a positive outcome between 2013 and 2016. This indicates that these two characteristics were treated by LFAS in a latter period. Access to remote areas in the North region, especially to indigenous communities, is difficult. In fact, out of 515 continuously functioning indigenous schools, 321 (or 62\%) were in the North region. 
Table 2. Multinomial Logit testing against control variables

\begin{tabular}{|c|c|c|c|c|}
\hline Variables & Lost Energy & No Energy & Elect. 2013-2016 & $\begin{array}{c}\text { Elect. Before } \\
2013 \\
\end{array}$ \\
\hline & 1 & 2 & 3 & 4 \\
\hline Number of Rooms & $\begin{array}{c}0.224 * * * \\
(0.0676)\end{array}$ & & $\begin{array}{c}0.403 * * * \\
(0.0314)\end{array}$ & $\begin{array}{c}0.607 * * * \\
(0.0289)\end{array}$ \\
\hline Indigenous Community & $\begin{array}{c}-0.0877 \\
(0.279)\end{array}$ & & $\begin{array}{l}0.0295 \\
(0.125)\end{array}$ & $\begin{array}{c}-0.426 * * * \\
(0.126)\end{array}$ \\
\hline Quilombola Community & $\begin{array}{c}1.358 * * * \\
(0.324)\end{array}$ & & $\begin{array}{c}0.860 * * * \\
(0.196)\end{array}$ & $\begin{array}{c}0.597 * * * \\
(0.184)\end{array}$ \\
\hline Northeast & $\begin{array}{l}0.0165 \\
(0.637)\end{array}$ & & $\begin{array}{c}0.729 * * \\
(0.285)\end{array}$ & $\begin{array}{c}0.905 * * * \\
(0.247)\end{array}$ \\
\hline North & $\begin{array}{c}0.290 \\
(0.623)\end{array}$ & Umitted & $\begin{array}{c}0.144 \\
(0.280)\end{array}$ & $\begin{array}{c}-0.441 * \\
(0.244)\end{array}$ \\
\hline South & $\begin{array}{c}-10.97 \\
(744.8)\end{array}$ & & $\begin{array}{c}2.035 * * \\
(0.883)\end{array}$ & $\begin{array}{c}2.313 * * * \\
(0.812)\end{array}$ \\
\hline Southeast & $\begin{array}{c}0.550 \\
(0.972)\end{array}$ & & $\begin{array}{c}1.062 * * \\
(0.431)\end{array}$ & $\begin{array}{c}1.484 * * * \\
(0.372)\end{array}$ \\
\hline Constant & $\begin{array}{c}-3.221 * * * \\
(0.645)\end{array}$ & & $\begin{array}{c}-1.748 * * * \\
(0.291)\end{array}$ & $\begin{array}{c}-1.345^{* * *} \\
(0.255)\end{array}$ \\
\hline Observations & 6,780 & 6,780 & 6,780 & 6,780 \\
\hline LR $\operatorname{chi} 2(21)$ & 1226.16 & & & \\
\hline Prob > chi 2 & 0 & & & \\
\hline Pseudo R2 & 0.0783 & & & \\
\hline Log likelihood & -7221.7351 & & & \\
\hline
\end{tabular}

Standard errors in parentheses

$* * * \mathrm{p}<0.01, * * \mathrm{p}<0.05, * \mathrm{p}<0.1$

For category (ii), the number of rooms (negative coefficient), the dummy for the Northeast region (positive coefficient), and the dummy for indigenous settlements (positive coefficient) are the only significant coefficients. First, the Northeast region is the poorest one and the primary focus of the program. The same logic applies to indigenous settlements. Moreover, results also show that the program focuses on smaller schools. Category (iii) represents only $2.85 \%$ of the total, and we consider it to be an exception. For category (iv), many variables have significant coefficients: distance (positive), indigenous (positive), quilombolas (negative) and all regional variables (negative, except for the Northeast, which is positive). This indicates that smaller and more isolated schools have a reduced probability of having electricity until 2016. In general, signals and magnitudes of the test (iv) and (ii) are very similar, indicating that schools that did not have electricity in 2013 can reach both states in 2016, as we intended to show. 
From this first result, we elaborate our second test to answer the question: does electricity access have positive effects on school dropout rates? We use a differences-in-differences approach (DD) to compare treated and untreated schools between 2013 and 2016. This method allows us to isolate the effects of policy on the dropout rate evolution. The Differences-in-Differences is a useful technique to compare the effect over time of two groups, one that was treated by the policy and the control group. Angrist and Pischke (2008) defines it as

$$
Y_{s t}=\alpha+\gamma \operatorname{Tr}_{s} \operatorname{Trs}_{s}+\lambda \mathrm{d}_{\mathrm{t}}+\beta\left(\operatorname{Tr}_{s} \cdot \mathrm{d}_{\mathrm{t}}\right)+\epsilon_{i s t}
$$

Where $T r$ is the treatment dummy and $d_{t}$ is the time dummy, with $t$ being the postintervention period. The interaction term indicates whether the treatment was before or after the intervention. In our case, $Y_{s t}$ is the dropout rate, by school $(s)$ in period $t$. The treatment variable is the access of electricity and $d_{t}$ is a dummy indicating if the observation is in $2016(=1)$ or in $2013(=0)$. Control dummies are added to support the estimation depending on the region and type of community of each school.

\subsection{Estimation and Results}

Figure 4 shows the dropout rate by electrification status. Overall, dropout rates fell in all categories including schools that never had energy had a higher rate compared to those which received electricity before 2016. Schools that lost electricity access between 2013 and 2016 have the highest abandonment rate, although this experience is rare and might be overestimated due to the number of observations. Schools that gained access to electricity between 2013 and 2016 have the lowest average dropout rate. Even though these schools also have the highest dropout rate declining (excluding schools that lost), compared to those which received electricity before 2013 (the most vulnerable ones) or never had electricity. This may validate our hypothesis that the benefits of electrification have an almost immediate impact on schools, which is diluted over time. On average, and without including any controls, schools that received electricity access performed 0.54 p.p. or $12.28 \%$ better in terms of reducing the dropout rate. 


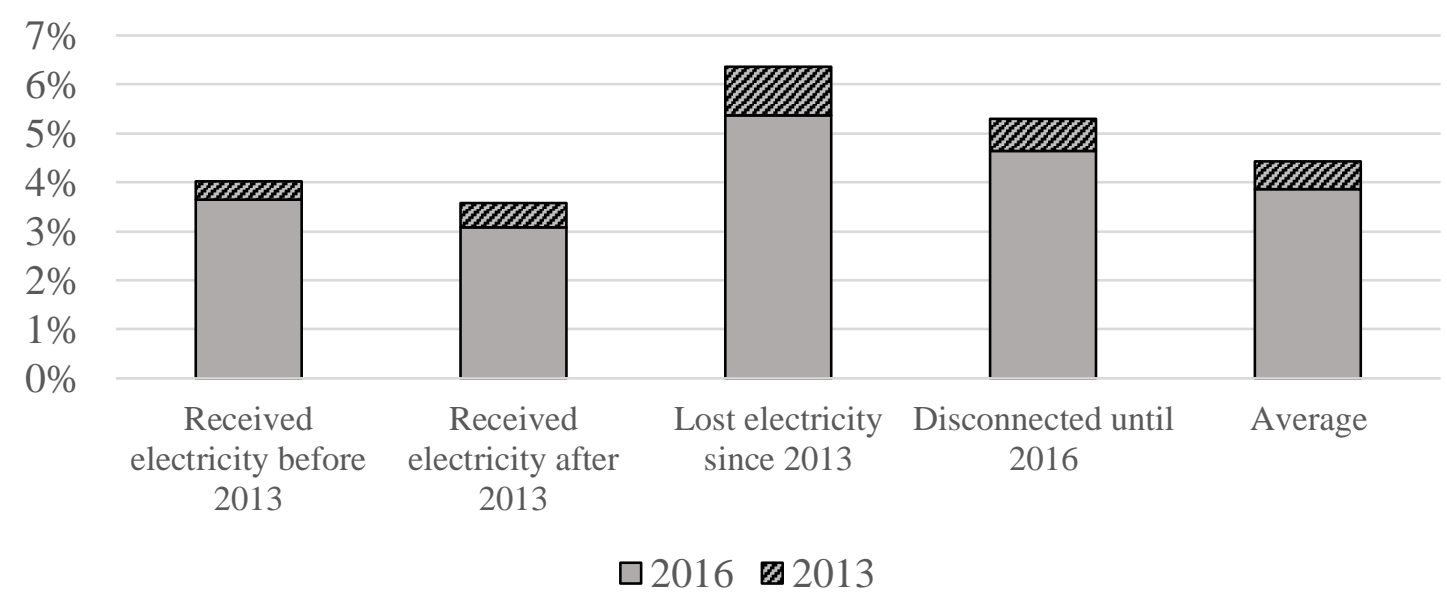

Figure 4. Mean dropout rate by electrification status, 2013 - 2016

Source: Our elaboration

We show the results of the differences-in-differences model below. 
Table 3 shows the simplest DD model without any other control variables, estimated by an Ordinary Least Square model. The time coefficient is negative (as expected by the descriptive statistics) but not significant. The coefficient of treatment dummy (indicating whether the school has access to electricity that year) indicates a significant negative effect of -0.01 . The effect is marginal. The interaction variable - time and treatment - is also negative, but not significant. The adjusted R-square of the regression is very low, indicating poor fitness, but the F-test shows that the specification is significant. 
Table 3. DD Estimation without controls

\begin{tabular}{lrrrrr}
\hline $\begin{array}{c}\text { Dropout Rate } \\
\text { (Initial Years) }- \text { in } \%\end{array}$ & Coefficient & \multicolumn{1}{c}{ Std. Error } & \multicolumn{1}{c}{$\mathrm{t}$} & $\begin{array}{c}\mathrm{p}- \\
\text { value }\end{array}$ & \\
\hline Time $(2013=0)$ & -0.0020 & 0.0021 & -0.9600 & 0.3390 & \\
Treatment (Electricity = 1) & -0.0110 & 0.0021 & -5.3100 & 0.0000 & $* * *$ \\
\hline DD Time\#Treatment & -0.0031 & 0.0029 & -1.0500 & 0.2930 & \\
\hline Constant & 0.0488173 & 0.0013318 & 36.66 & 0 & $* * *$ \\
\hline Observations & 13,404 & & & & \\
F(27, 13376) & 29.81 & & & & \\
Prob $>$ F & 0 & & & & \\
R-square & 0.0066 & & & & \\
Adj. R-square & 0.0064 & & & & \\
\hline
\end{tabular}

The second estimation ${ }^{10}$ includes two control variables and their interactions: regions omitting Central-West - and Type of Community - omitting non-indigenous and nonquilombolas communities (Table 4). The DD coefficients - Time, Treatment and Interaction - are significant (at 95\% Confidence Level for Treatment and Interaction and at 90\% Confidence Level for Time). Time and Treatment shows a negative coefficient, and interaction shows a positive coefficient.

The fitness of the model is indeed still very low with R-square around 0.39 , but the F-test indicates that the model is overall significant. This means that omitted variables may be influencing the dropout rate at school, as expected. These variables include, but are not limited to, performance, infrastructure, child-labor, lack of public transportation to access school, parental background, etc.

Using control variable averages, we can summarize the effect of program treatment (provide access to school) by the electrification status we proposed above (Figure 5). On average, schools with access to electricity in 2016 performed much better in reducing dropout rates. Schools that received electricity between 2013 and 2016 had an average estimated decrease of around 1 percentage point (or $27 \%$ improvement) in the dropout rate, and schools that received electricity before 2013 had a reduction of -0.6 percentage point (or 16\% improvement) due to electrification. Conversely, the effect on untreated

\footnotetext{
${ }^{10}$ A third estimation was made (results in Annex 1) including the number of rooms in schools as a proxy of the size of school. The coefficient for this variable is significant but very small ( 0.0004 p.p. / room) and the average effect is 0.0008 p.p., the result is negligible, meaning that the size of school is not important in determining the dropout rate in LFAS beneficiaries. All other results are maintained.
} 
schools was between 0.19 p.p. and -0.14 p.p. ( $+3 \%$ and $-3 \%$, respectively). This effect, as expected, is very near to zero.

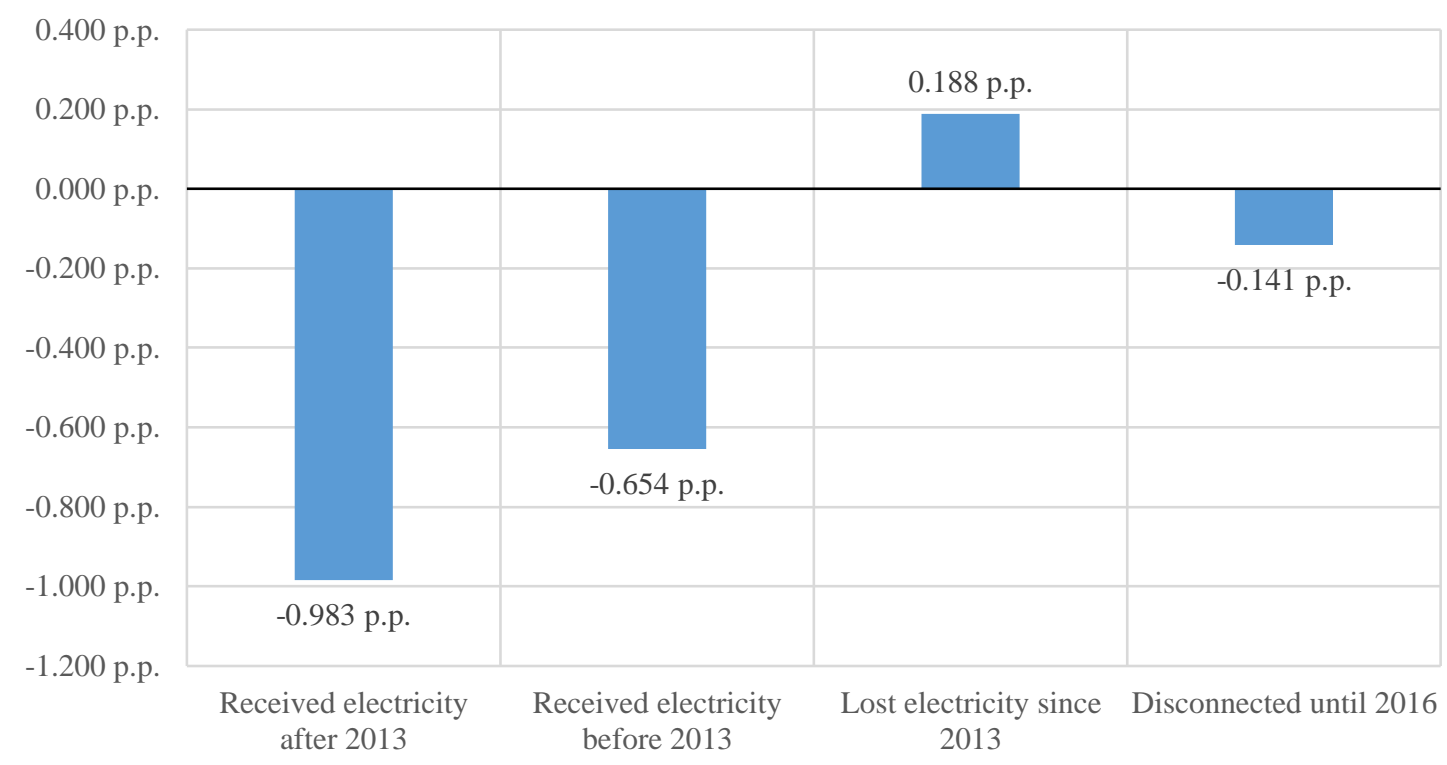

Figure 5. Marginal effects of electrification on dropout rate by status

\section{Source: Our elaboration}

The only significant regional dummy is North, with 0.03 p.p. above the Central-West dropout rate. Although not significative, the other regional dummies show the expected signal, coherent with their socio-economic issues: positive for the Northeast, and negative for the South and Southeast. The community control variables are significant for both Indigenous (with a positive coefficient) and Quilombolas (with a negative coefficient). This result is also coherent since indigenous communities tend to be the most isolated, culturally diverse, and with a specific schooling system. 
Table 4. DD Estimation with Regional and Community control variables

\begin{tabular}{|c|c|c|c|c|}
\hline Dropout Rate of initial years & Coefficient & Std. Error & $\mathrm{t}$ & $p$-value \\
\hline Time $(2013=0)$ & -0.0284 & 0.0171 & -1.6500 & 0.0980 \\
\hline Treatment $($ Electricity $=1)$ & -0.0320 & 0.0150 & -2.1300 & 0.0330 \\
\hline DD Time\#Treatment & 0.0444 & 0.0220 & 2.0200 & 0.0430 \\
\hline \multicolumn{5}{|l|}{ Regional Variables } \\
\hline Northeast & 0.0053 & 0.0110 & 0.4800 & 0.6290 \\
\hline North & 0.0379 & 0.0108 & 3.5000 & 0.0000 \\
\hline Southeast & -0.0190 & 0.0171 & -1.1100 & 0.2660 \\
\hline South & -0.0300 & 0.0329 & -0.9100 & 0.3610 \\
\hline \multirow{2}{*}{\multicolumn{5}{|c|}{ Type of Community }} \\
\hline Indigenous Settlements & & & & \\
\hline Quilombolas Communities & -0.0288 & 0.0080 & -3.6000 & 0.0000 \\
\hline \multicolumn{5}{|l|}{ Regional DD } \\
\hline Northeast\#Time & 0.0329 & 0.0174 & 1.9000 & 0.0580 \\
\hline North\#Time & 0.0181 & 0.0170 & 1.0600 & 0.2880 \\
\hline Southeast\#Time & 0.0230 & 0.0291 & 0.7900 & 0.4290 \\
\hline South\#Time & 0.0338 & 0.0683 & 0.5000 & 0.6200 \\
\hline Northeast\#Treatment & 0.0326 & 0.0152 & 2.1400 & 0.0320 \\
\hline North\#Treatment & 0.0192 & 0.0151 & 1.2700 & 0.2040 \\
\hline Southeast\#Treatment & 0.0312 & 0.0214 & 1.4600 & 0.1450 \\
\hline South\#Treatment & 0.0538 & 0.0425 & 1.2700 & 0.2060 \\
\hline Northeast\#Treatment\#Time & -0.0526 & 0.0223 & -2.3600 & 0.0180 \\
\hline North\#Treatment\#Time & -0.0424 & 0.0221 & -1.9200 & 0.0550 \\
\hline Southeast\#Treatment\#Time & -0.0404 & 0.0338 & -1.2000 & 0.2320 \\
\hline South\#Treatment\#Time & -0.0667 & 0.0768 & -0.8700 & 0.3850 \\
\hline \multicolumn{5}{|l|}{ Community DD } \\
\hline Indigenous\#Time & 0.0115 & 0.0075 & 1.5300 & 0.1250 \\
\hline Quilombolas\#Time & 0.0259 & 0.0131 & 1.9700 & 0.0490 \\
\hline Indigenous\#Treatment & 0.0349 & 0.0085 & 4.0900 & 0.0000 \\
\hline Quilombolas\#Treatment & 0.0169 & 0.0113 & 1.5000 & 0.1320 \\
\hline Indigenous\#Treatment\#Time & -0.0350 & 0.0117 & -2.9900 & 0.0030 \\
\hline Quilombolas\#Treatment\#Time & -0.0188 & 0.0166 & -1.1300 & 0.2590 \\
\hline Constant & 0.0245521 & 0.0118518 & 2.07 & 0.038 \\
\hline Observations & 13404 & & & \\
\hline $\mathrm{F}(27,13376)$ & 20.2 & & & \\
\hline Prob $>\mathrm{F}$ & 0 & & & \\
\hline R-square & 0.0392 & & & \\
\hline Adj. R-square & 0.0372 & & & \\
\hline
\end{tabular}




\section{Conclusions}

The objective of this study was to evaluate the impact of the Light for All in Schools program on the dropout rate in initial years of schooling. Although the benefits of electrification on learning can be huge, their effect on educational outcomes requires more research, especially in isolated and less developed regions.

First, we discussed the relationship between electrification, lighting and school dropout rates in primary education. Then, we described the LFAS program and its objectives and governance structure. Lastly, we estimated the impact of the program on the dropout rate of schools using data from the School Census and data provided by the Ministry of Mines and Energy.

Our results show that the effects of electrification programs on the dropout rate are significant. Schools that received electricity via the program before 2013 experienced a16\% improvement in the dropout rate in three years and schools that were treated by the program between 2013 and 2016 experienced a27\% improvement in three years due to access to electricity. Comparably, schools that did not receive it had a near-to-zero effect on the dropout rate due to the lack of electricity.

In general terms, we conclude that Light for All in Schools was a successful program in reducing the dropout rate in vulnerable rural schools. In absolute terms, the benefit affected only $2 \%$ of the schools in Brazil (6\% of rural schools) - where electricity access reaches $99.3 \%$ - but it represents a significant contribution to the last mile problem. This result encourages the adoption of comparable programs in other regions experiencing problems similar to those of isolated communities.

These vulnerable rural communities are plagued by problems such as higher levels of poverty, worse school infrastructure, and child labor. Providing electrification to their schools is an import way to improve access to quality education and ensure that students finish (at least) their basic education. This might help these children to break the cycle of intergenerational poverty by increasing human capital. 


\section{References}

Alves, T.; Silva, R. Moreira da. (2013). Estratificação das oportunidades educacionais no brasil: contextos e desafios para a oferta de ensino em condições de qualidade para todos. Educação \& Sociedade, Centro de Estudos Educação e Sociedade, v. 34, n. 124.

Angrist, J. D., \& Pischke, J. S. (2008). Mostly harmless econometrics: An empiricist's companion. Princeton university press.

Bhattacharyya, S.C. Review of alternative methodologies for analysing off-grid electricity supply. Renew. Sustain. Energy Rev. 2012, 16, 677-694

Belfield, C. (2000), Economic principles for education: theory and evidence, Cheltenham, RU e Northamton, EUA: Edward Elgar.

Dinkelman, T.,2011.The Effects of Rural Electrification on Employment: New Evidence from South Africa.Am.Econ.Rev.101(7),3078-3108.

Diniz, A.S.A.C., França, E. D., Câmara F., Morais, P. M. R., Vilhena L. (2006). The Important Contribution of Photovoltaics in a Rural School Electrification Program. IEEE 4th World Conference on Photovoltaic Energy Conversion.

Dunn, R., Krimsky, J. S., Murray, J. B., \& Quinn, P. J. (1985). Light up their lives: A review of research on the effects of lighting on children's achievement and behavior. The Reading Teacher, 38(9), 863-869.

Felicio, F. d. (2008). Fatores associados ao sucesso escolar: Levantamento, classificação e análise dos estudos realizados no brasil. São Paulo: Fundação Itaú Social.

INEP. (2018). Relatório do $2^{\circ}$ ciclo de monitoramento das metas do PNE. Brasília. Retrieved 25 October 2018 from https://goo.g1/DPyczH.

Jimenez, R. (2017). Development Effects of Rural Electrification. Inter-American Development Bank. Policy Brief No IDB-PB-261.

Kassouf, A. L. (2015). Evolução do trabalho infantil no Brasil. Sinais Sociais, v. 09, p. 09-45.

Khandker,S.R.,Samad,H.A.,Ali,R.,Barnes,D.F.,2012. Who benefits most from rural electrification? Evidence in India. Policy Research Working Paper 6095, World Bank 〈http://elibrary.worldbank.org/doi/pdf/10.1596/1813-9450-6095〉.

Lipscomb M., Mobarak A.M., Barham T. (2013). Development Effects of Electrification: Evidence from the Topographic Placement of Hydropower Plants in Brazil. American Economic Journal: Applied Economics. Vol.5, No2, April 2013.

Leon, F. L. L., Menezes-Filho, N. A. (2002). Reprovação, avanço e evasão escolar no brasil. Pesquisa e Planejamento Econômico, v. 32, n. 3, p. 417-452.

Machin, S. A. Vignoles (eds.). (2005). What's the good of education: The economics of education in the UK. Princeton Univ. Press.

Menard, S. (2010). Logistic regression: From introductory to advanced concepts and applications. Sage. 
Ney, M. G.; Souza, P. M.; Ponciano, N. J. (2010). Desigualdade de acesso à educação e evasão escolar entre ricos e pobres no Brasil rural e urbano. InterScience Place, v. 3, p. 33-55.

Neri, M. C. O paradoxo da evasão e as motivações dos sem escola. Educação básica no Brasil: construindo o país do futuro. Rio de Janeiro: Elsevier, 2009.

Pieri, R. G. d., Santos, A. A. D. (2014). Uma Proposta para o Índice de Infraestrutura Escolar e o Índice de Formação de Professores. Brasília: Instituto

Nacional de Estudos e Pesquisas Educacionais Anísio Teixeira. Retrieved 25 October 2018 from https://goo.gl/dst9pE.

Rumberger, R. W.; Palardy, G. J. (2005). Test scores, dropout rates, and transfer rates as alternative indicators of high school performance. American educational research journal, v. 42, n. 1, p. 3-42.

Sleegers, P. J. C., Moolenaar, N. M., Galetzka, M., Pruyn, A., Sarroukh, B. E., \& Van der Zande, B. (2013). Lighting affects students' concentration positively: Findings from three Dutch studies. Lighting research \& technology, 45(2), 159-175.

Teixeira, W. M., Menezes-Filho, N. A. (2012) Estimando o retorno à educação do Brasil considerando a legislação educacional brasileira como um instrumento. Revista de Economia Política, v. 32, p. 479-496.

Verner, D., \& Cardoso, A. R. (2007). School drop-out and push-out factors in Brazil: The role of early parenthood, child labor, and poverty. The World Bank.

Welland, A. (2017). Education and the electrification of rural schools. Smart Villages. Retrieved 25 October 2018 from https://goo.g1/NTA7dn.

World Bank (2016). SE4ALL Global Tracking Framework. World Bank, International Energy Agency, and the Energy Sector Management Assistance Program. Available at: https://data.worldbank.org/indicator/EG.ELC.ACCS.Z 
Annex 1. Estimation including the number of rooms at the School

\begin{tabular}{|c|c|c|c|c|c|c|}
\hline $\begin{array}{l}\text { Dropout Rate } \\
\text { Initial Years }\end{array}$ & Coef. & Std. Err. & $\mathrm{t}$ & $P>t$ & \multicolumn{2}{|c|}{ [95\% Conf. Interval] } \\
\hline Time & -0.0305 & 0.0171 & -1.7800 & 0.0750 & -0.0641 & 0.0031 \\
\hline Treatment & -0.0269 & 0.0150 & -1.7900 & 0.0740 & -0.0564 & 0.0026 \\
\hline Time $*$ Treatment & 0.0449 & 0.0220 & 2.0500 & 0.0410 & 0.0019 & 0.0880 \\
\hline North & 0.0346 & 0.0108 & 3.1900 & 0.0010 & 0.0134 & 0.0559 \\
\hline Northeast & 0.0015 & 0.0110 & 0.1300 & 0.8950 & -0.0202 & 0.0231 \\
\hline Southeast & -0.0227 & 0.0171 & -1.3200 & 0.1860 & -0.0562 & 0.0109 \\
\hline South & -0.0342 & 0.0329 & -1.0400 & 0.2980 & -0.0987 & 0.0302 \\
\hline Time * North & 0.0200 & 0.0170 & 1.1800 & 0.2400 & -0.0134 & 0.0534 \\
\hline Time * Northeast & 0.0349 & 0.0174 & 2.0100 & 0.0450 & 0.0009 & 0.0689 \\
\hline Time * Southeast & 0.0249 & 0.0291 & 0.8600 & 0.3910 & -0.0320 & 0.0819 \\
\hline Time * South & 0.0358 & 0.0682 & 0.5200 & 0.6000 & -0.0979 & 0.1696 \\
\hline Treatment $*$ North & 0.0160 & 0.0151 & 1.0600 & 0.2890 & -0.0136 & 0.0457 \\
\hline Treatment $*$ Northeast & 0.0282 & 0.0152 & 1.8500 & 0.0640 & -0.0016 & 0.0581 \\
\hline Treatment $*$ Southeast & 0.0333 & 0.0214 & 1.5500 & 0.1200 & -0.0087 & 0.0752 \\
\hline Treatment $*$ South & 0.0508 & 0.0425 & 1.1900 & 0.2320 & -0.0325 & 0.1340 \\
\hline $\begin{array}{l}\text { Treatment } * \text { Time } * \text { North } \\
\text { Treatment } * \text { Time } *\end{array}$ & -0.0431 & 0.0220 & -1.9500 & 0.0510 & -0.0863 & 0.0001 \\
\hline Northeast & -0.0531 & 0.0223 & -2.3900 & 0.0170 & -0.0967 & 0.0095 \\
\hline Treatment $*$ Time $*$ & & & & & & \\
\hline Southeast & -0.0418 & 0.0338 & -1.2400 & 0.2160 & -0.1080 & 0.0245 \\
\hline Treatment $*$ Time $*$ South & -0.0675 & 0.0767 & -0.8800 & 0.3790 & -0.2179 & 0.0829 \\
\hline Indigenous & -0.0286 & 0.0080 & -3.5800 & 0.0000 & -0.0443 & 0.0129 \\
\hline Quilombola & 0.0123 & 0.0048 & 2.5500 & 0.0110 & 0.0029 & 0.0218 \\
\hline Time * Indigenous & 0.0260 & 0.0131 & 1.9800 & 0.0480 & 0.0002 & 0.0517 \\
\hline Time * Quilombola & 0.0120 & 0.0075 & 1.6000 & 0.1090 & -0.0027 & 0.0268 \\
\hline Treatment * Indigenous & 0.0167 & 0.0112 & 1.4800 & 0.1390 & -0.0054 & 0.0387 \\
\hline Treatment * Quilombola & 0.0343 & 0.0085 & 4.0300 & 0.0000 & 0.0176 & 0.0510 \\
\hline Treatment $*$ Time $*$ & & & & & & \\
\hline Indigenous & -0.0186 & 0.0166 & -1.1200 & 0.2630 & -0.0512 & 0.0140 \\
\hline Treatment $*$ Time $*$ & & & & & & \\
\hline Quilombola & -0.0349 & 0.0117 & -2.9800 & 0.0030 & -0.0579 & 0.0119 \\
\hline Number of Rooms & -0.0016 & 0.0004 & -3.8000 & 0.0000 & -0.0024 & 0.0008 \\
\hline Constant & 0.0306 & 0.0110 & 2.7900 & 0.0050 & 0.0091 & 0.0521 \\
\hline Number of obs & 13,406 & & & & & \\
\hline $\mathrm{F}(28,13377)$ & 20.01 & & & & & \\
\hline Prob $>$ F & 0 & & & & & \\
\hline R-squared & 0.0402 & & & & & \\
\hline Adj R-squared & 0.0382 & & & & & \\
\hline
\end{tabular}

